\title{
Peran Agama dalam Aktivitas Pelestarian Alam: Studi Deskriptif pada Front Nahdliyyin untuk Kedaulatan Sumber Daya Alam, FNKSDA
}

\author{
Dede Setiawan \\ Jurusan Studi Agama-Agama \\ Fakultas Ushuluddin UIN Sunan Gunung Djati Bandung, Indonesia \\ setiawandede1999@gmail.com
}

\begin{abstract}
The purpose of this study was to discuss the role of religion in nature conservation activities carried out by the Nahdliyyin Front for Natural Resources Sovereignty. This research is a qualitative research with descriptive method through theoritical analysis and literature study. The results of this study indicate that nature conservation activities the Nahdliyyin Front for Natural Resources Sovereignty has a role for religion. Namely in the form of a power boost called Religious Assets. The religious assets include; 1) Transcendent Motivation; 2) Shared Identity; 3) Socio-Geographical Religion; 4) Special Legitimacy; and 5) Institutional Interests. This research has significance for the development of the discourse of Religious Studies in the field of Religion and Ecology. Considering that the discourse on the relationship between religion and the issue of nature conservation is still considered minimally studied. The conclusion of this study is that religion has a role in the form of encouragement of strength through moral and institutional messages in an effort to preserve nature.
\end{abstract}

Keywords: Nature conservation, Religious assets, Religious studies.

\begin{abstract}
Abstrak
Tujuan penelitian ini adalah untuk membahas peran agama pada aktivitas pelestarian alam yang dilakukan oleh Front Nahdliyyin untuk Kedaulatan Sumber Daya Alam. Penelitian ini adalah penelitian kualitatif dan menggunakan metode deskriptif melalui analisis teori serta studi kepustakaan. Hasil dari penelitian ini menunjukkan bahwa di dalam aktivitas pelestarian alam pada Front Nahdliyyin untuk Kedaulatan Sumber Daya Alam terdapat peran agama. Yakni berupa dorongan kekuatan yang disebut Aset Agama. Aset Agama tersebut antara lain; 1) Motivasi Transenden; 2) Identitas Bersama; 3) Sosio-Geografis Religi; 4) Legitimasi Istimewa;
\end{abstract}


dan 5) Kepentingan Institusional. Penelitian ini memiliki signifikansi untuk pengembangan diskursus Ilmu Studi Agama dibidang Agama dan Ekologi. Mengingat diskursus mengenai relasi Agama dan isu pelestarian alam masih dinilai minim kajiannya. Kesimpulan pada penelitian ini adalah agama memiliki peran berupa dorongan kekuatan melalui pesan moral dan institusional dalam upaya pelestarian alam.

Kata kunci: Aset agama, Pelestarian alam, Studi agama.

\section{Pendahuluan}

Salah satu permasalahan yang luput dari perhatian, namun dampaknya mengancam masa depan manusia adalah masalah kelestarian alam. Padahal, masalah kelestarian alam adalah permasalahan bersama, karena berkaitan langsung dengan keberlangsungan hidup manusia. Tesis mengenai keterlibatan agama dalam isu kelestarian alam pernah disinggung oleh Lynn White dalam artikelnya yang berjudul The Historical Roots of Our Ecological Crisis (1967). Inti dalam tulisannya, White menuduh agama sebagai dalang dari semua praktik pengrusakan alam. Sebab, agama memposisikan manusia itu sempurna di atas makhlukmakhluk lainnya. Sehingga manusia merasa memiliki kuasa untuk mengeksploitasi alam (Anwar \& Rosyad, 2021). Tuduhan tersebut oleh para peneliti yang concern pada kajian agama dan ekologi dianggap tidak mendalam. Karena pada porsinya sebagai sebuah intitusi, agama memiliki seperangkat legitimasi dalam aktivitas pelestarian alam (Smith, 1996). Dapat dilihat dari beberapa organisasi yang mengatasnamakan golongan keagamaan tertentu yang melakukan gerakan pelestarian alam.

Sejumlah penelitian terdahulu pernah menjelaskan permasalahan kelestarian alam dan lingkungan. Dengan berbagai pendekatan serta fokus masalah yang diteliti. Antara lain skripsi dari Hipzon (2018) berjudul "Pelestarian Lingkungan dalam Pandangan Islam" dari UIN Raden Intan Lampung. Penelitian tersebut menggunakan pendekatan teologis dan memakai metode kualitatif. Hipzon (2018) menyatakan bahwa lingkungan dan manusia merupakan makhluk yang berdampingan yang tidak bisa dipisahkan. Lingkungan pada hakikatnya merupakan suatu syarat mutlak bagi kelangsungan hidup secara menyeluruh dan hal tersebut sesuai dengan anjuran agama Islam (Hipzon, 2018). Artikel ilmiah dari Stevanus, K. (2019) yang berjudul "Pelestarian Alam sebagai Perwujudan Mandat Pembangunan: Suatu Kajian Etis-Teologis" terbitan Kurios: Jurnal Teologi dan Pendidikan Agama Kristen. Artikel tersebut menggunakan penelitian kualitatif dengan metode deskriptif berdasarkan Alkitab, dan juga menggunakan studi kepustakaan dengan menganalisis literatur yang 
membahas permasalahan pelestarian alam. Dari kajian etis-teologis penelitian ini, menurut Stevanus, K. (2019) manusia adalah pengelola dan pelestari alam, mengelola serta melestarikannya merupakan implementasi ajaran kasih kepada sesama. Dengan pemahaman itu, diharapkan kelestarian alam senantiasa dikelola secara bijak, bertanggungjawab, dan seproduktif mungkin oleh manusia untuk kepentingan serta kelangsungan generasi yang akan datang (Stevanus, 2019). Artikel ilmiah dari Amri, U. (2016) yang berjudul “Konservasi Berbasis Komunitas Religi: Membedah Peran Ormas dalam Upaya Melestarikan Sumber Daya Alam di Indonesia" terbitan Masyarakat Indonesia: Jurnal Ilmu-Ilmu Sosial Indonesia. Penelitian tersebut menggunakan pendekatan kualitatif dengan metode deskriptif. Amri, U. (2016) berpendapat bahwa aktivitas konservasi yang dilakukan oleh komunitas religi berasal dari gagasan hasil kombinasi antara nilai-nilai etika, gerakan lingkungan global, dan eko-teologi Islam. Gagasan tersebut terwujud pada dua ormas Islam terbesar dan tertua di Indonesia, Muhammadiyah dan Nahdlatul Ulama, dengan melakukan praktik-praktik antara lain: 1) mitigasi kegiatan perusak alam terutama deforestasi; 2) melakukan reboisasi atau penghijauan; dan 3) mengupayakan penyediaan sumber energi alternatif (Amri, 2016).

Penelitian terdahulu memberikan kegunaan untuk menyusun kerangka berpikir pada penelitian agar alurnya berjalan dengan logis dan koheren (Darmalaksana, 2020). Pelestarian alam adalah kepegiatan yang berupaya dalam pengelolaan sumber daya alam dan ekosistem dengan tujuan mempertahankan sifat dan bentuk dari alam (Kurniadi, 2020). Pelestarian alam juga sering disebut konservasi yang berasal dari Bahasa Inggris yakni concervation. Dalam praktiknya, pelestarian alam dapat dilakukan secara individual dan komunal. Agama memiliki peran pada kedua praktik tersebut. Baik secara individual ataupun komunal, peran agama dalam beberapa kasus pengrusakan alam memberikan dorongan berupa ajaran moral sampai pada tataran yang lebih kuat seperti legitimasi intitusional yang dilakukan komunal untuk menjaga sumber daya alam.

Smith, C. (1996) mengatakan bahwa agama memiliki kekuatan untuk melakukan gerakan sosial. Kekuatan itu disebut dengan aset agama (Smith, 1996). Aset agama adalah teori yang mengemukakan bahwa agama pada prinsipnya menyediakan 'alat' untuk melakukan suatu gerakan sosial. Dalam teori ini disebutkan setidaknya ada lima item dalam agama yang dianggap sebagai kekuatan untuk melakukan gerakan sosial, yaitu: 1) Motivasi Transenden; 2) Identitas Bersama; 3) Sosio-Geografis Religi; 4) Legitimasi Istimewa; dan 5) Kepentingan Institusional (Smith, 1996). Kelima indikator tersebut dijadikan acuan bahwa agama - baik dogma atau posisinya sebagai lembaga, berperan sebagai kekuatan dalam suatu gerakan sosial. Front Nahdliyyin untuk Kedaulatan Sumber Daya Alam - 
selanjutnya FNKSDA, adalah gerakan sosial para warga Nahdliyyin yang berupaya untuk menjaga kelestarian alam.

Berdasarkan paparan di atas, penulis kemudian menyusun sebuah formula penelitian berupa tujuan, asumsi, dan pertanyaan penelitian (Darmalaksana, 2020). Tujuan dari penelitian ini adalah untuk membahas peran agama pada aktivitas pelestarian alam yang dilakukan oleh FNKSDA. Diasumsikan bahwa agama dengan kekuatan yang dimilikinya, berperan dalam aktivitas pelestarian alam yang dilakukan oleh FNKSDA. Pertanyaan penelitian ini adalah bagaimana peran agama dalam aktivitas pelestarian alam yang dilakukan oleh FNKSDA. Hasil yang diharapkan dari penelitian ini adalah dapat dijadikan sebagai rujukan penelitianpenelitian selanjutnya, yang bertemakan pelestarian alam atau lingkungan hidup. Dan juga, dapat memperkaya khazanah intelektual dalam kajian ilmu studi agama.

\section{Metode Penelitian}

Jenis penelitian ini adalah penelitian kualitatif-deskriptif (Darmalaksana, 2020). Penelitian kualitatif dikatakan sebagai rangkaian penelitian yang mampu menghasilkan data berupa deskriptif kata-kata baik tertulis atau lisan dari objek atau perilaku manusia yang dapat diamati (Moleong, 2007). Metode deskriptif dimaksudkan untuk eksplorasi dan klarifikasi mengenai sesuatu fenomena, kondisi, atau kenyataan sosial, dengan jalan mendeskripsikan sejumlah asumsi yang dijadikan masalah dalam penelitian (Sanapiah, 1995). Serta menggunakan analisis teori dan studi kepustakaan. Analisis teori adalah salah satu teknik dalam penelitian yang menjadikan teori sebagai acuan dari kebenaran, fakta, dan keadaan objek yang diteliti. Analisis teori digunakan sebagai alat pembacaan realitas yang kemudian dikonstruksi menjadi deskripsi yang argumentatif (Hamad, 2007). Studi kepustakaan dipakai untuk memperkaya literatur penelitian, agar kemudian dapat ditarik sebuah kesimpulan.

\section{Hasil dan Pembahasan}

Hasil penelitian dan pembahasan di bawah ini:

\section{Profil Singkat FNKSDA}

Front Nahdliyyin untuk Kedaulatan Sumber Daya Alam atau disingkat FNKSDA adalah organisasi yang dideklarasikan pada tanggal 8 Desember 2013 di Pondok Pesantren Tebuireng, Jombang. Ditetapkan pada 3 April 2015 pada Musyawarah Nasional yang pertama di Kuningan, Jawa Barat (FNKSDA, 2015). Organisasi yang menghimpun gerakan warga NU ini dibentuk bersama para kaum buruh tani. Penamaan organisasi dengan kata 'front' memiliki filosofis bahwa gerakan ini senantiasa berada di garis terdepan untuk memperjuangkan kedaulatan sumber daya alam dan kelestariannya. Serta menyematkan kata 'Nahdliyyin' untuk menunjukkan 
bahwa gerakan ini diisi oleh para warga NU (Murtadho, 2021). Meskipun tidak terafiliasi langsung secara struktural kepada Pengurus Besar Nahdlatul Ulama (PBNU), melainkan hanya terikat secara kultural, eksistensi FNKSDA diakui sebagai gerakan alternatif berbasis kultural untuk mewadahi para warga NU yang memiliki kesadaran akan isu-isu kelestarian alam dan keinginan akan terwujudnya kedaulatan atas pengelolaan sumber daya alam (Murtadho, 2021).

FNKSDA berazaskan Pancasaila dan UUD 1945. Organisasi yang berkedudukan di Jombang ini, memiliki sifat nasionalis, religius, inklusif, militan, demokratis, dan independen (FNKSDA, 2015). Dengan bentuk organisasi yang cenderung kepada persyarikatan dan jaringan, serta berprinsip pada prinsip-prinsip Ahlusunnah wal Jama'ah dan kearifan lokal, menjadikan FNKSDA berkomitmen pada garis-garis perjuangan untuk mencapai tujuan organisasi, yaitu: 1) Memperkuat dan mendukung perjuangan ekonomi-politik dan kultural masyarakat korban konflik Sumber Daya Alam (SDA) di Indonesia; dan 2) Mengokohkan kedaulatan masyarakat dalam tata milik, tata kelola, dan tata guna SDA (FNKSDA, 2015).

\section{Gambar 1. Lambang Organisasi FNKSDA}

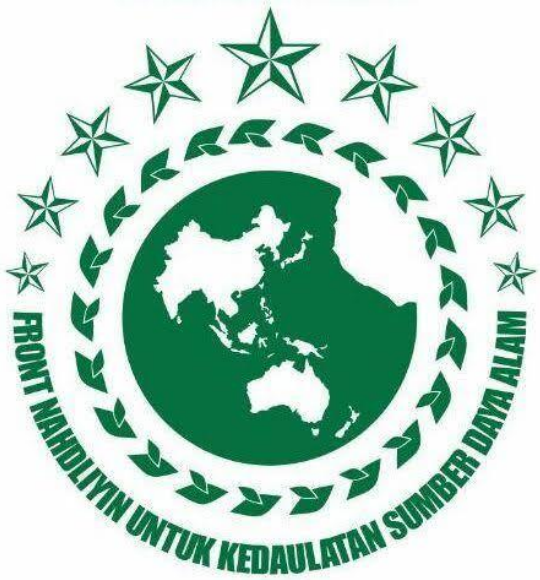

FNKSDA sebagaimana organisasi pada umumnya, juga memiliki lambang pada organisasinya untuk dijadikan ikon organisasi. Lambang organisasi berupa gambar bola dunia yang dikelilingi oleh rantai. Melambangkan bahwa FNKSDA berkomitmen menjaga kelestarian bumi dan sumber daya alam di dalamnya. Di atas rantai yang mengelilingi bola dunia terdapat sembilan bintang yang merepresentasikan filosofis Nahdlatul Ulama sebagai identitas kultural yang melekat pada FNKSDA. Dimana, sembilan bintang dalam filosofi lambang NU sendiri memiliki makna sembilan Walisongo, bintang paling besar menandakan kepemimpinan Nabi Muhammad, dan empat bintang menandakan 
kepemimpinan Khulafaur Rasyidin. Di bawahnya terdapat tulisan melengkung yang bertuliskan Front Nahdliyyin untuk Kedaulatan Sumber Daya Alam yang merupakan nama organisasi. Warna lambang seluruhnya didominasi oleh warna hijau. Selain melambangkan relasi kultural NU, yang notabene juga didominasi warna hijau, juga melambangkan kedaulatan masyarakat yang 'hijau' akan kelestarian alam dan tata kelola SDA.

Penyematan kata 'Nahdliyyin' pada nama organisasi FNKSDA ini banyak mengundang polemik. Hal ini dikarenakan FNKSDA tidak terafiliasi secara struktural atau tidak langsung sebagai badan yang sifatnya otonom di bawah naungan PBNU. Kendati demikian, nama 'Front Nahdliyyin' akhirnya disepakati untuk menentukan kejelasan subjek gerakan (Widayati \& Suparjan, 2019). Kata 'Nahdliyyin' sering disematkan untuk menunjukkan bahwa seseorang itu termasuk warga NU atau dipahami sebagai orang-orang yang mengamalkan ajaran-ajaran serta prinsip Ahlusunnah wal Jam'ah. Dengan tujuan yang salah satunya adalah mewacanakan pengarusutamaan permasalahan kelestarian alam serta perjuangan untuk kedaulatan tata kelola SDA, bukan dipahami sebagai sebuah praktik 'makar' warga NU dari tubuh NU secara struktural. Penggunaan kata 'Nahdliyyin' bukan ditujukan untuk merepresentasikan NU struktural, tetapi untuk menggalang solidaritas dengan kesamaan identitas sebagai warga NU (Widayati \& Suparjan, 2019).

FNKSDA didirikan sebagai respon atas keresahan dari permasalahan konflik pengelolaan SDA. Gerak FNKSDA berorientasi pada pengamalanpengamalan Islam yang Rahmatan lil 'Alamin. Bagi FNKSDA, moderatisme yang diusung oleh struktural NU, tidak mampu untuk mengakomodir permasalahan horizontal seperti konflik agraria dan tata kelola SDA. Dibutuhkan pijakan ideologis alternatif untuk mengawal gerakan FNKSDA.

“.. kita bergerak untuk mengkampanyekan nilai-nilai sosialisme Islam dan Islam yang Rahmatan lil 'Alamin. Islam sebagai agama yang memberikan rahmat untuk seluruh alam, kami tafsirkan dalam bentuk gerakan untuk melakukan perlawanan kepada kapitalisme dan pihakpihak yang melakukan eksploitasi terhadap kelestarian alam" (Komunikasi dengan Roy Murtadho, Koordinator Nasional FNKSDA, 19 Juli 2021).

Gerakan FNKSDA menjadi lebih leluasa untuk kemudian berjejaring sampai ke daerah-daerah, dengan upayanya mengkampanyekan sosialisme Islam. Juga lebih luwes dalam melakukan mobilitas komunal. Sehingga mampu membangun relasi-relasi yang beragam sesama pegiat kelestarian alam, di antaranya: WALHI, Kristen Hijau, Kader Hijau Muhammadiyah, YLBHI, dan Kontras (Murtadho, 2021). Meskipun 
FNKSDA mengusung identitasnya sebagai Nahdliyyin, namun agenda dan gerakan yang dilakukannya beragam, tidak hanya ditujukan untuk warga NU saja. Agenda-agenda seperti diskusi, mengadakan sekolah-sekolah, melakukan pernyataan sikap, advokasi, dan demonstrasi. Isu-isu yang mereka bangun untuk menjaga kelestarian alam pun banyak. Tidak hanya kampanye atas perusakan alam seperti deforestasi, melakukan reboisasi, dan mitigasi bencana. Mereka mengkampanyekan antidepelovmentalisme, anti-kapitalisme, bahkan teologi pembebasan. Karena bagi FNKSDA, mengeksploitasi alam dengan mengatasnamakan pembangunan dan investasi, adalah cara kerja para kapitalis dan wajib hukumnya untuk melawan. Mengabaikan ekologi demi kepentingan ekonomi tidak akan memperpanjang umur hidup manusia. Manusia tetap membutuhkan alam sebagai penopang kehidupannya (Amri, 2016).

\section{Aktivitas Pelestarian Alam}

Aktivitas yang dilakukan oleh FNKSDA tertuang dalam pokok-pokok perjuangan organisasi. Hal-hal dalam pokok-pokok perjaungan tersebut, alih-alih menanam pohon, mereka melakukan sesutu yang lebih mendasar. Di dalamnya, terdapat beberapa misi yang diemban oleh FNKSDA untuk berjuang mencapai tujuan organisasi. Pokok-pokok perjuangan tersebut ialah: 1) Melibatkan diri secara aktif dalam perjuangan masyarakat korban konflik SDA melawan kekuatan kapitalisme dan upaya perusakan alam; 2) Membangun basis pengetahuan dan kesadaran kritis masyarakat dalam tata milik, tata kelola, dan tata guna SDA yang berdaulat; 3) Mencegah dan menyelesaikan persoalan-persoalan horizontal yang terjadi dalam konflik SDA; 4) Mendorong terbentuknya serikat-serikat, jaringan-jaringan, dan kantong-kantong perjuangan kedaulatan SDA; dan 5) Aktif dalam kerjakerja solidaritas gerakan rakyat dan membangun kerjasama dengan lembaga lain dalam memperjuangkan kedaulatan SDA (FNKSDA, 2015).

\section{Gambar 2. Demonstrasi FNKDA}

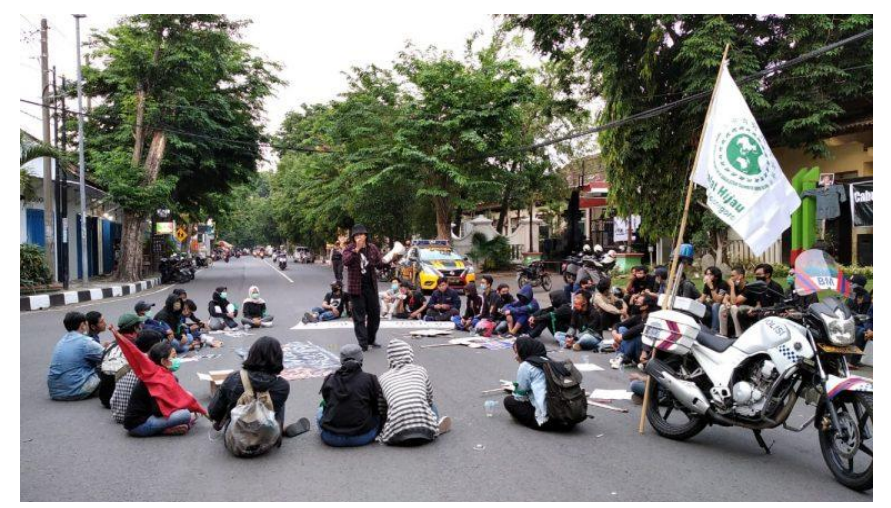

Gambar 2 Demonstrasi FNKSDA terhadap praktik penambangan pasir besi di Kulon Progo, Yogyakarta (Sumber: www.fnksda.or.id) 
Pokok-pokok perjuangan tersebut kemudian dijadikan acuan FNKSDA dalam mengembangkan kepegiatan mereka dengan melakukan agenda-agenda yang relevan. Seperti mengecam dan melakukan protes atas bencana industri yang disebabkan PT. Lapindo Brantas yang menyemburkan lumpur panas, yang berdampak pada banyaknya lahan dan ruang hidup para warga NU Sidoarjo hilang dilahap lumpur panas Lapindo. Kasus pembangunan bandara di Yogyakarta yang mengundang penolakkan dari warga, penambangan pasir besi di Kulon Progo yang mendapat resistensi dari warga sekitar, serta praktik-praktik eksploitasi alam, perampasan ruang hidup lainnya oleh korporasi-korporasi dan pelaku lainnya di berbagai daerah seperti Kebumen, Urutsewu, Jombang, dan daerah-daerah di Sumatra, Kalimantan, dan Sulawesi, turut diperjuangkan oleh FNKSDA (Muslich, 2021).

Selain melakukan aksi dengan protes terhadap pihak yang melakukan eksploitasi kelestarian alam, FNKSDA juga melakukan serangkaian agenda pendidikan yang menunjang isu-isu lingkungan hidup. Seperti mengadakan Sekolah Agraria, Sekolah Adat, dan Sekolah Lingkungan. Sekolah-sekolah ini dilakukan dari tingkatan nasional hingga daerah, dan bertujuan memberikan kesadaran kritis masyarakat akan pentingnya tata kelola SDA yang berdaulat dan berkeadilan. Sehingga masyarakat dalam melakukan protes memiliki bekal intelektual yang mengorganik.

“.. kami melakukan pembangunan kesadaran kritis kepada masyarakat akan pentingnya hak mereka dalam kepemilikkan dan pengelolaan lahan serta ruang hidup yang ada. Melalui pendidikan yang berprinsip pada haraqah (gerakan) Nahdliyyin, yakni Ahlusunnah wal Jama'ah An-Nahdliyyah. Mbah Hasyim dulunya petani, dan penting bagi kami untuk terus mengembangkan pengetahuan para pengelola SDA agar mereka berdaulat" (Komunikasi dengan Muslich Muhammad, Sekretaris Jenderal Komite Nasional FNKSDA, 19 Juli 2021).

\section{Gambar 3. Kegiatan Pesantren Agraria}

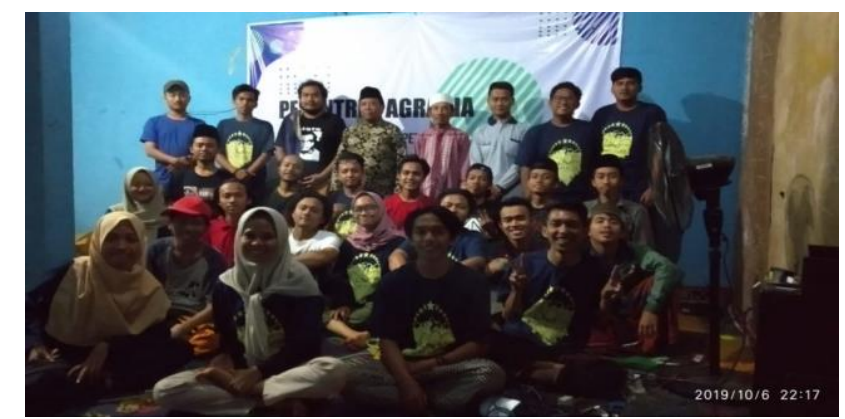

Gambar 3 Kegiatan Pesantren Agraria yang dilakukan FNKSDA Bandung Raya pada tahun 2019 (Sumber: Dokumentasi Pribadi). 
Pendidikan melalui sekolah-sekolah yang diadakan oleh FNKSDA, selain untuk mengembangkan kesadaran kritis masyarakat, juga bertujuan untuk mencegah terjadinya persoalan-persoalan horizontal yang terjadi dalam konflik SDA. Materi-materi yang disampaikan dalam sekolahsekolah pun ditentukan secara sistematis dalam AD/ART. Antara lain Fikih Lingkungan dan SDA; Pemetaan Potensi Kaum Marjinal; Ancaman Sumber Daya Masyarakat; Analisis Sosio-Ekologi, Sosio-Ekonomi, SosioKultural, Sosio-Politik, dan Ekonomi-Politik dengan kritik atas Kapitalisme sebagai kerangka berpikir; Hukum Positif, Hukum Agama, Hukum Adat, dan Hukum Agraria; Teori dan Praktik Pengorganisasian dan Pergerakan Massa (FNKSDA, 2015).

Sebagaimana disebutkan sebelumnya, pihak atau sosok yang dianggap sebagai common enemy atau 'musuh bersama' bagi FNKSDA, adalah para korporat dan pemodal yang mengeksploitasi alam melalui dalih pembangunan serta investasi. FNKSDA sadar bahwa 'musuh' mereka memiliki kekuatan untuk merepresi, mengintimidasi, dan bahkan mengkriminalisasi masyarakat pengelola SDA (Widayati \& Suparjan, 2019). Maka, selain melakukan pendidikan kepada masyarakat, FNKSDA juga melakukan kaderisasi untuk menunjang basis massa. Dalam kaderisasi itulah muatan materi sekolah-sekolah disampaikan. Elemen masyarakat yang difokuskan oleh FNKSDA untuk dikader adalah organisasi yang berhubungan dengan NU baik secara struktural ataupun kultural - seperti GP Ansor, Fatayat NU, IPNU-IPPNU, dan PMII; warga marjinal atau pinggiran yang berada di ruang-ruang konflik SDA; dan dari kalangan mahasiswa. Kaderisasi dilakukan dengan tujuan agar terbentuknya jejaring dan kerja solidaritas dalam memperjuangkan kelestarian alam dan kedaulatan pengelolaan SDA (Ubaidillah, 2018).

Sebagai organisasi yang terbilang muda dibandingkan dengan organisasi-organisasi lain yang menjadi Badan Otonom (Banom) NU, FNKSDA telah memiliki 22 Koordinator Daerah (Koorda) di seluruh Indonesia (Ubaidillah, 2018). Dengan basis massa di tiap daerahnya, FNKSDA terus melakukan kaderisasi, pendidikan, advokasi, penelitian dan pengembangan. Sebagaimana ditegaskan dalam AD/ART pasal 8 bahwa "setiap koordinator daerah berkewajiban untuk memastikan terlaksananya agenda kaderisasi, pendidikan, advokasi, dan berjalannya Biro Litbang" (FNKSDA, 2015). Dan sebagai sebuah gerakan sosial, FNKSDA juga melakukan sikap politik. Seperti pada saat momentum pemilu 2019, FNKSDA menyatakan sikap untuk abstain dalam perhelatan hajat demokrasi lima tahunan itu.

“.. kita ini baik secara perseorangan ataupun komunal, secara tegas memperjuangkan ekonomi-politik melalui gerakan kultural Nahdliyyin, untuk melawan kapitalisme. Karena kami jujur, merasa kecewa dengan 
orang-orang yang berada di struktural NU, yang ternyata banyak berjejaring dengan para kapitalis, dengan para pemodal, dengan para korporat. Mereka semua itu 'aktor' politik negeri ini. Kami pro terhadap rakyat kecil. Yang tanahnya dirampas, ruang hidupnya dimusnahkan. NU didirikan dengan tujuan kemaslahatan umat. Tapi melihat orang-orang di dalam struktural NU yang malah memaslahatkan diri dengan para 'musuh', maka kami yang mengambil peran" (Komunikasi dengan Roy Murtadho, Koordinator Nasional FNKSDA, 19 Juli 2021).

Apa yang dilakukan oleh FNKSDA, perlahan-lahan mulai mematahkan asumsi Lynn White yang mengatakan bahwa agama sebagai dalang dari praktik-praktik perusakan alam. Penyadaran kritis yang dilakukan oleh FNKSDA, banyak menggunakan 'kekuatan-kekuatan' agama. Sepintas, wacana FNKSDA untuk mengkampanyekan sosialisme Islam seperti hal yang tidak memungkinkan. Mengingat konsep semacam itu dipandang sulit untuk diterima dan diwujudkan dalam sebuah gerakan. Sebab, subjek gerakan FNKSDA yang notabene adalah warga NU, yang tergolong kedalam Islam tradisional yang berpaham moderatisme, sudah dipupuk oleh ketundukkan pada otoritas wahyu serta serangkaian ortodoksinya (Ubaidillah, 2018). Namun, dengan 'modal' karakter warga Nahdliyyin tersebut, FNKSDA memanfaatkan keadaan. Gagasan-gagasan progresif FNKSDA, diselaraskan dengan kondisi Nahdliyyin yang tradisionalistik. Dengan mengedapankan dialog kultural dan mengakomodir keresahan korban konflik SDA secara faktual apa adanya, membuat FNKSDA sangat dekat dengan masyarakat.

\section{Peran Agama dalam Aktivitas FNKSDA}

Diskursus tentang keterlibatan agama dalam isu lingkungan, dalam beberapa literatur, diawali oleh asumsi Lynn White pada tahun 1967 yang menyebutkan bahwa, agama dan berbagai otoritasnya adalah sumber masalah dari krisis lingkungan (Anwar \& Rosyad, 2021). White menuturkan bahwa 'mandat' yang ada pada teks-teks suci agama bersifat antroposentris, yang memposisikan manusia di atas makhluk-makhluk lainnya. Sehingga manusia menganggap dan memperlakukan alam hanya secara instrumental saja, tanpa ada penghormatan lebih terhadap alam. Mengakibatkan menjamurnya praktik eksploitasi alam demi memenuhi egosentris manusia belaka. Asumsi ini kemudian memantik para intelektual dan cendekiawan di bidang ilmu studi agama, untuk kemudian ikut dalam diskursus keterkaitan agama dalam krisis lingkungan. Agama dan ekologi menjadi sub-tema besar ilmu studi agama pada akhir abad 20. Mengingat dunia sedang gencar-gencarnya diterpa revolusi industri dan modernisme Barat, yang berdampak pada kerusakan SDA (Yafie, 2006). 
Salah satu filsuf besar dari Iran yang memiliki fokus perhatian pada permasalahan kelestarian alam adalah Sayyed Hossein Nasr (2016). Nasr berpandangan bahwa bumi kita saat ini mengalami krisis yang sangat serius akibat dari ulah manusia yang serakah. Manusia mengeksploitasi alam ini dan tidak menunjukkan sikap ramah kepada alam. Manusia modern dengan segala kemajuan ilmu pengetahuannya, telah sangat jauh dari spiritualitas agama (Firdaus, 2021). Membuat bumi semakin mendekati titik kebinasaannya. Pada titik inilah, peran agama untuk mengatasi probematika krisis lingkungan dibutuhkan (Maftukhin, 2016). Peran-peran agama dapat diimplementasikan secara beragam. Salah satunya adalah tesis yang dikemukakan Smith, C. (1996) bahwa agama berperan dalam setiap gerakan-gerakan sosial dalam bentuk aset yang menjadi 'kekuatan' bagi suatu gerakan. Aset tersebut, lanjut Smith, menjadi sumber dorongan untuk melakukan aktivisme dalam gerakan sosial (Smith, 1996).

Teori aset agama yang dikemukakan Smith, memiliki beberapa item yang dapat digunakan untuk menopang gerakan sosial. Meskipun itemitem ini tidak semua didapati dalam setiap gerakan sosial, namun itemitem ini menjadi acuan bahwa agama berperan dalam gerakan tersebut (Jamil, 2013). Item-item tersebut sebagaimana dikemukakan di awal, adalah: 1) Motivasi Transenden; 2) Identitas Bersama; 3) Sosio-Geografis Religi; 4) Legitimasi Istimewa; dan 5) Kepentingan Institusional. Kelima item tersebut selalu melekat dalam gerakan sosial. Dalam kelima item tersebut, terdapat indikator-indikator yang menjadi ciri sebuah gerakan sosial itu dikatakan menggunakan aset agama. Baik gerakan sosial yang berbasis keagamaan ataupun sekuler. Maksudnya, aset agama ini dapat ditemukan dalam gerakan-gerakan sosial yang berupa organisasi keagamaan, masyarakat, atau bahkan ideologis (Smith, 1996). Dan sebagai organisasi gerakan sosial yang memiliki bentuk persyarikatan dan jaringan, FNKSDA dinilai menggunakan aset dalam agama untuk dijadikan kekuatan pada setiap aktivitas kepegiatannya.

Asumsi penulis yang mengatakan bahwa agama memiliki peran dalam aktivitas kepegiatan FNKSDA, didasarkan para realitas yang terjadi di lapangan dan pernyataan yang diungkapkan oleh informan yang berkomunikasi dengan penulis. Agar mempermudah analisis, penulis sajikan dalam bentuk tabel di bawah ini:

Tabel 1. Analisis Teoritis Aset Agama

\begin{tabular}{|l|l|}
\hline \multicolumn{1}{|c|}{ Pertama } & \multicolumn{1}{|c|}{ Motivasi Transenden } \\
\hline Legitimasi protes & FNKSDA menggunakan teks-teks suci \\
bersumber dari "Yang & agama untuk dijadikan landasan teologis \\
Mahatinggi" atau "Yang & mereka dalam melakukan gerakan protes. \\
Suci";
\end{tabular}




\begin{tabular}{|c|c|}
\hline $\begin{array}{l}\text { Perintah moral untuk } \\
\text { keadilan, kebebasan; }\end{array}$ & $\begin{array}{l}\text { Perintah moral dari teks suci agama bahwa } \\
\text { manusia sebagai wakil Tuhan di muka bumi. }\end{array}$ \\
\hline $\begin{array}{l}\text { Motivasi Kuat dengan } \\
\text { Ikon, Ritual, Lagu, } \\
\text { Kesaktian, dan Pidato; }\end{array}$ & $\begin{array}{l}\text { Memakai lambang organisasi yang } \\
\text { merepresentasikan semangat organisasi } \\
\text { dalam bergerak. }\end{array}$ \\
\hline $\begin{array}{l}\text { Ideologi sebagai landasan } \\
\text { gerakan. }\end{array}$ & $\begin{array}{l}\text { Mengkampanyekan konsep sosialisme Islam } \\
\text { sebagai pengejawantahan dari Islam } \\
\text { Rahmatan lil 'Alamin. }\end{array}$ \\
\hline Kedua & Identitas Bersama \\
\hline $\begin{array}{l}\text { Identifikasi umum di } \\
\text { antara kumpulan orang- } \\
\text { orang; }\end{array}$ & $\begin{array}{l}\text { Memanfaatkan identitas Nahdliyyin untuk } \\
\text { dijadikan subjek gerakan dan melakukan } \\
\text { kaderisasi secara sistematis. }\end{array}$ \\
\hline $\begin{array}{l}\text { Berbagi super-identitas } \\
\text { secara nasional dan } \\
\text { transnasional. }\end{array}$ & $\begin{array}{l}\text { Merangkul kaum marjinal dan mustadhaffin } \\
\text { (kaum lemah dan tertindas) untuk } \\
\text { menggalang solidaritas gerakan. }\end{array}$ \\
\hline Ketiga & \\
\hline Dispersi Geografis; & $\begin{array}{l}\text { Berjejaring ke daerah-daerah untuk } \\
\text { mendorong gerakan organisasi secara masif. }\end{array}$ \\
\hline $\begin{array}{l}\text { Difusi sosial dan asosiasi } \\
\text { lintas sektoral; }\end{array}$ & $\begin{array}{l}\text { Berjejaring dengan aliansi masyarakat yang } \\
\text { sama-sama memiliki konsen gerakan } \\
\text { pelestarian alam. }\end{array}$ \\
\hline $\begin{array}{l}\text { Hubungan organisasi } \\
\text { transnasional. }\end{array}$ & $\begin{array}{l}\text { Memiliki relasi kultural dengan Nahdlatul } \\
\text { Ulama dan menjalin kerja-kerja solidaritas } \\
\text { bersama organisasi sejenis. }\end{array}$ \\
\hline Keempat & Legi \\
\hline $\begin{array}{l}\text { Legitimasi politik dalam } \\
\text { opini publik; }\end{array}$ & $\begin{array}{l}\text { FNKSDA berorientasi pada perjuangan } \\
\text { ekonomi-politik dengan berdasar pada kritik } \\
\text { atas kapitalisme, serta menganggapnya } \\
\text { sebagai common enemy. }\end{array}$ \\
\hline $\begin{array}{l}\text { Perlindungan agama } \\
\text { sebagai "ruang terbuka" } \\
\text { terakhir. }\end{array}$ & $\begin{array}{l}\text { Memegang prinsip Ahlusunnah wal Jama'ah } \\
\text { An-Nahdliyyah dan Kearifan Lokal untuk } \\
\text { melegitimasi gerakan agar tidak terlalu } \\
\text { radikal secara ideologis dan aksi. }\end{array}$ \\
\hline Kelima & Kepentingan Insti \\
\hline $\begin{array}{l}\text { Perlawanan terhadap } \\
\text { Insitusi. }\end{array}$ & $\begin{array}{l}\text { Melawan korporasi dan pihak-pihak yang } \\
\text { melakukan eksploitasi terhadap SDA, yang } \\
\text { mengakibatkan kerusakan alam. }\end{array}$ \\
\hline
\end{tabular}

Tabel 1 mengabstraksikan analisis teoritis aset agama dalam aktivitas pelestarian alam yang ada pada FNKSDA.

Tabel 1 di atas memberikan gambaran apa-apa saja yang ada pada setiap gerak aktivitas yang melingkupi FNKSDA, sesuai dengan indikator 
pada teori aset agama. Pertama, Motivasi Transenden. Semua gerakan sosial menghadapi masalah mengenai motivasi anggota dan mempertahankan komitmen terhadap tujuan bersama, terutama ketika aktivitas kepegiatan tersebut membutuhkan biaya yang besar (Ziaulhaq, 2020). Pada titik ini, agama mampu menawarkan beberapa solusi penting dan unik untuk masalah ini. Motivasi transenden ini bersumber dari semua teks suci dari agama yang dapat ditafsirkan dengan arah yang berbeda; di mana kepentingan politik, sosial, ekonomi bisa saja dipertentangkan dengan tafsir dari teks suci yang sejalan dengan kebutuhan atau tujuan suatu gerakan (Smith, 1996). Dengan kata lain, sebuah gerakan memiliki keterbukaan dan fleksibilitas penafsiran teks suci yang dapat memfasilitasi berbagai bentuk organisasi dan strategi, tergantung kemungkinan kebutuhan legitimasi gerakan tersebut.

FNKSDA menggunakan teks suci agama (ayat Al-Qur'an) untuk dijadikan motivasi gerakan pelestarian alam mereka. Seperti mencatut ayat pada surat ar-Ruum [30] : 41 yang berbunyi: "Telah nampak kerusakan di darat dan di laut disebabkan karena perbuatan manusia, supaya Allah merasakan kepada mereka sebagian dari (akibat) perbuatan mereka, agar mereka kembali (ke jalan yang benar)." Ayat tersebut dijadikan 'pemantik' kesadaran oleh FNKSDA, dalam rangka penyadaran kritis masyarakat tentang pentingnya tata kelola SDA yang berdaulat. Atau memakai surat al-Baqarah [2] : 30 yang berbunyi: "Sesungguhnya Aku telah hendak menjadikan seorang khalifah di muka bumi." Ayat ini digunakan untuk memotivasi semangat perjuangan yang dilakukan oleh FNKSDA dalam menjaga kelestarian alam. Karena makna khalifah adalah penjaga atau perawat muka bumi (Ilyas, 2016). Selain menggunakan teks suci agama, aktivitas kepegiatan FNKSDA pun dimotivasi oleh dorongan ideologi. FNKSDA mengkampanyekan sosialisme Islam sebagai sebuah konsep implementatif dari Islam yang Rahmatan lil 'Alamin. Hal ini kemudian membuat garapan taktis FNKSDA juga ada pada koridor perjuangan kelas.

Kedua, Identitas Bersama. Gerakan sosial harus membangun dan mempertahankan identitas kolektif yang menandakan diri mereka, apa yang mereka perjuangkan, dan bentuk masyarakat yang diharapkan. Menciptakan dan memelihara identitas bersama membutuhkan banyak pekerjaan; melalui pengalaman gerakannya, identitas bersama dibangun untuk menggambarkan kode moral dan budaya, ideologi, nilai-nilai, simbol, pandangan dunia, serta mampu mempertahankan kebermaknaan dalam gerakan tersebut dalam menghadapi kenyataan sosial (Smith, 1996). Selain dari fungsi ekspresif solidaritas, identitas bersama mampu meningkatkan kapasitas instrumen gerakan dalam efektivitas organisasi dan perjuangan politik. Agama, sebagai identitas kolektif yang mapan, mampu memberikan sumber daya berharga dalam menciptakan dan memelihara identitas bersama dalam gerakan sosial (Ziaulhaq, 2020). 
FNKSDA memanfaatkan identitas Nahdliyyin yang melekat pada anggota, kader, dan simpatisannya. Identitas Nahdliyyin memberikan peluang besar untuk gerak kolektif organisasi. Selain memanfaatkan identitas Nahdliyyin, FNKSDA juga merangkul kaum marjinal dan mustadhaffin (rakyat kecil lemah dan tertindas), dalam rangka mempertahankan moral untuk memperjuangkan kaum yang lemah. FNKSDA juga berusaha dalam menjaga kultural Nahdliyyin agar tidak sampai mereduksi tatanan budaya dan nilai, meskipun ada ideologi yang ingin mereka coba ejawantahkan, demi pandangan mereka atas dunia yang lestari dan diharapkan bisa dimaknai secara bersama. Hal tersebut tercermin dalam soliditas setiap kader FNKSDA di setiap mengkampanyekan isu pelestarian alam.

Ketiga, Sosial Geografis Religi. Maksudnya, agama memiliki kekuatan untuk memobilisasi kelas sosial serta menyebar ke wilayah-wilayah secara ekspansif (Smith, 1996). Agama sering menikmati karakteristik sosial dan geografis yang dapat mempromosikan kekuatan gerakan sosial. Dalam beberapa kasus, aset ini sangat strategis bagi para aktivis gerakan sosial yang tersebar di wilayah geografis suatu negara yang bertentangan hanya dengan terkonsentrasi pada satu wilayah atau pusat kota. Agama memiliki struktur komunikasi yang mampu menghubungkan dan mengkoordinir antar aktivis yang tersebar luas dan memiliki latar belakang sosial yang berbeda-beda dengan pusat kepemimpinan yang mapan (Ziaulhaq, 2020). Termasuk, memperkuat rekuitmen gerakan sosial yang tersebar di antarwilayah, baik nasional ataupun internasional, dengan berbagai keuntungan, seperti rekuitmen anggota potensial; mengurasi persepsi publik bahwa gerakan tersebut hanya bersifat lokal; meningkatkan jumlah perwakilan; dan mempersulit represi negara atau gerakan kontra terhadap gerakan tersebut. Dengan kata lain, penyebaran geografis agama dapat diterjemahkan sebagai kekuatan strategis untuk gerakan sosial. Jaringanjaringan yang dibangun FNKSDA adalah bukti aset ini bekerja. Membangun koordinator di setiap daerah, serta beraliansi dengan organisasi sejenis yang memiliki konsen pada isu-isu kelestarian alam. Selain itu, relasi kultural yang dimiliki FNKSDA dengan NU, salah satu ormas terbesar di Indonesia, juga memberikan kekuatan lebih dalam melakukan ekspansi gerakan. Dispersi geografis diartikan sebagai ekspansi atau penyebaran gerakan menuju wilayah yang lebih luas. Mulanya, FNKSDA hanya bergerak di wilayah Jawa, tepatnya di Jombang. Namun, pada perkembangannya mampu menyebar ke wilayah-wilayah lain seperti Sumatra dan Kalimantan.

Keempat, Legitimasi Istimewa. Agama seringkali merasa memiliki tanggungjawab secara moral, dan mengizinkan para pembangkang politik beroperasi di dalam institusi keagamaan mereka; apabila otoritas atau organisasi tersebut tidak secara proaktif dan nonkoperatif melawan musuh bersama untuk memperjuangkan hak-hak orang-orang yang tertindas 
(Smith, 1996). Dengan demikian, agama dapat menggunakan posisinya yang relatif istimewa untuk membantu mempertahankan sisa-sisa otonomi masyarakat sipil, untuk mempertahankan suara perlawanan, dan untuk mempersiapkan dasar bagi oposisi gerakan sosial yang lebih luas ketika musuh mulai mengalah (Ziaulhaq, 2020). Tentunya, hal tersebut menjadi aset perlindungan yang berharga bagi gerakan sosial yang tertekan oleh musuh. FNKSDA memiliki legitimasi sebagai 'warga sipil NU' yang merasa kecewa pada individu yang berada dalam struktural Jam'iyyah yang dekat dengan para korporat dan pemodal yang melakukan eksploitasi SDA. Dengan dasar ideologis 'kiri Islam' mereka, FNKSDA bahkan secara terang-terangan bergerak layaknya 'partai'. Menentukan sikap politik dan mengakomodir massa lewat kritik atas kapitalisme. Namun, FNKSDA tetap berpegang teguh pada prinsip ajaran Ahlusunnah wal Jama'ah dan kearifan lokal, untuk dijadikan 'ruang terbuka dan perlindungan terakhir' bagi mereka agar tetap bisa bergerak secara berkelanjutan bersama masyarakat dalam upaya-upaya melestarikan alam dan mewujudkan tata kelola SDA yang berdaulat. Prinsip tasamuh (toleransi); tawazun (seimbang); tawasuth (moderat); ta'adul (adil); dan amar ma'ruf nahi munkar (menyeru kebaikan, melarang kebatilan). Lima prinsip inilah yang menjadi acuan perjuangan FNKSDA untuk menyebarluaskan kampanye pelestarian alam.

Kelima, Kepentingan Institusional. Dalam beberapa kasus, agama dapat membantu penyebab gerakan sosial, tidak hanya melalui legitimasi yang diistimewakan, tetapi sebagai hasil dari pertahanan tujuan kepentingan institusionalnya sendiri (Smith, 1996). Efek positif yang dihasilkan untuk gerakan sosial dapat dirasakan secara langsung atau tidak langsung. Hal tersebut bisa terjadi dalam bentuk perlawanan institusional terhadap perambahan negara atas kedaulatan rakyat. Misal, negara menjadi aktor terbesar daripada praktik pengrusakan alam. Ketika ini terjadi, lembaga keagamaan dapat menjadi pusat aktivisme anti-rezim. Dan gerakan-gerakan non-berbasis agama yang sama-sama menentang negara dapat mengambil manfaat dari aset sikap agama ini, dari retorika dan ritual penentangan, sumber daya institusional, dan aliansi politik. Dalam kasus FNKSDA, mereka mengaliansi diri untuk bersama melawan praktik negara yang melakukan deforestasi, melanggengkan developmentalisme, dengan dalih pembangunan ekonomi, dengan cara-cara etis-moralis yang mengacu pada nilai-nilai dan aset yang ada dalam agama.

\section{Kesimpulan}

Dengan menggunakan analisis teori sebagai alat pembacaan realitas, yang kemudian dikonstruksi menjadi deskripsi yang utuh dan argumentatif, dapat ditemukan bahwa agama memiliki peranan penting dalam gerak aktivitas pelestarian alam FNKSDA. Peran agama itu mewujud dalam bentuk aset yang digunakan sebagai sumber kekuatan 
dari gerakan FNKSDA. Aset-aset tersebut ialah Motivasi Transenden, Identitas Bersama, Sosio-Geografis Religi, Legitimasi Istimewa, dan Kepentingan Institusional. Aset-aset tersebut secara garis besar membuktikan bahwa agama berperan dalam aktivitas pelestarian alam yang dilakukan FNKSDA melalui pesan-pesan moral dan institusional. Penulis sadar dalam proses penyusunan tulisan ini, masih banyak kekurangan. Namun, penulis memiliki harapan agar penelitian ini bisa bermanfaat bagi penelitian-penelitian kedepannya. Terkhusus penelitian yang mengangkat isu kelestarian alam atau lingkungan hidup. Dan juga, hasil dari penelitian ini dapat dijadikan sebagai pemantik pagi para civitas akademika Jurusan Studi Agama-Agama, Fakultas Ushuluddin, UIN Sunan Gunung Djati Bandung, agar lebih mengembangkan wacana dan diskursus ilmu studi agama ke berbagai sektor kajian. Mengingat kajian mengenai agama dan ekologi, masih dinilai minim pengkajiannya.

\section{Ucapan Terima Kasih}

Terima kasih penulis haturkan kepada seluruh pihak yang terlibat dalam riset dan penulisan penelitian ini. Terkhusus untuk kawan-kawan dari FNKSDA yang banyak berdiskusi dengan penulis. Terima kasih juga kepada Bapak Dr. Wahyudin Darmalaksana, M.Ag. selaku Dekan Fakultas Ushuluddin, yang telah membimbing penulis dalam kegiatan Kelas Menulis. Serta kepada civitas akademika Jurusan Studi Agama-Agama, Kakanda Dr. Dadang Darmawan, M.Ag., selaku Ketua Jurusan; Bapak Dr. Ilim Abdul Halim, M.Ag., selaku Sekretaris Jurusan; Ayahanda Drs. Tatang Zakaria, M.Ag., dan Kakanda Asep Saeful Mimbar, M.Ag., selaku Dosen Pembimbing I dan II. Tanpa mereka, penulis tak akan mungkin sampai pada titik perjuangan sekarang ini. Kepada Kang Zia, dosen pengampu mata kuliah Gerakan Keagamaan Baru, yang telah banyak menginspirasi penulis lewat diskusi-diskusi yang beliau pantik selama perkuliahan dari rumah di tengah pandemi ini. Dan kepada para senior Korps Alumni Himpunan Mahasiswa Islam (KAHMI) Fakultas Ushuluddin, yang sedikit banyaknya telah mendukung baik moral ataupun materi bagi penulis untuk terus berproses mewujudkan pribadi muslim yang paripurna. Kepada kawankawan di HMI, IPMAKAB, HMJ Studi Agama-Agama, yang telah mewarnai proses selama perkuliahan di UIN Sunan Gunung Djati Bandung. Dan yang paling utama, penulis haturkan terima kasih sebesarbesarnya kepada kedua orang tua. Terima kasih telah memberikan peluh keringat untuk penulis, sehingga dapat mengenyam pendidikan tinggi. Penulis persembahkan dan dedikasikan seluruh proses perkuliahan dan hasil penelitian ini, untuk Almarhum Bapak dari penulis. Al-Fatihah. 


\section{Daftar Pustaka}

Amri, U. (2016). Konservasi Berbasis Komunitas Religi: Membedah Peran Ormas Keagamaan Dalam Upaya Melestarikan Sumber Daya Alam Di Indonesia. Masyarakat Indonesia, 38(1), 23-46.

Anwar, S., \& Rosyad, R. (2021). Pemikiran dan Aplikasi Teologi Lingkungan di Pesantren Cicalengka Kabupaten Bandung. Jurnal Iman dan Spiritualitas, 1(2).

Darmalaksana, W. (2020). Metode Penelitian Kualitatif Studi Pustaka dan Studi Lapangan. Pre-print Digital Library UIN Sunan Gunung Djati Bandung.

Darmalaksana, W. (2020). Template Penulisan Artikel. Jurnal Penelitian Ilmu Ushuluddin.

Firdaus, M. Y. (2021). Iktibar Kehidupan. Cianjur: Innovasi Publishing.

FNKSDA. (2015). Anggaran Dasar \& Anggaran Rumah Tangga Front Nahdliyyin untuk Kedaulatan Sumber Daya Alam. Komite Nasional FNKSDA.

Hamad, I. (2007). Lebih Dekat dengan Analisis Wacana. Mediator: Jurnal Komunikasi, 8(2), 325-344.

Hanief, L., Sari, N., \& Sanjaya, A. (2019). Kampanye Lingkungan Hidup Forum Komunitas Hijau dalam Pelestarian Alam di Kota Banjarmasin. KOMUNIDA: Media Komunikasi dan Dakwah, 9(1), 5365.

Hipzon. (2018). Pelestarian Lingkungan dalam Pandangan Islam. Lampung: UIN Raden Intan Lampung.

Ilyas, R. (2016). Manusia Sebagai Khalifah dalam Perspektif Islam. Mawa'izh: Jurnal Dakwah dan Pengembangan Sosial Kemanusiaan, 7(1), 169-195.

Jamil, A. (2013). Islam dan Kebangsaan: Teori dan Praktik Gerakan Sosial Islam di Indonesia (Studi atas Front Umat Islam Kota Bandung). Harmoni, 12(1), 130-143.

Kurniadi, M. R. (2020, Juli 17). Arti Pelestarian Alam di Kamus Besar Bahasa Indonesia (KBBI). Diambil kembali dari Lektur.id: https:// lektur.id/arti-pelestarian-alam

Maftukhin. (2016). Teologi Lingkungan Perspektif Sayyed Hossein Nasr. Dinamika Penelitian: Jurnal Penelitian IAIN Tulungagung, 338-352.

Moleong, L. J. (2007). Metode Penelitian Kualitatif. Bandung: Remaja Rosdakarya.

Murtadho, R. (2021, Juli 19). Apakah FNKSDA menjalin kerjasama dengan pihak lain. (D. Setiawan, Pewawancara)

Murtadho, R. (2021, Juli 19). Bagaimana Sejarah FNKSDA. (D. Setiawan, Pewawancara)

Muslich, M. (2021, Juli 19). Apa aksi konkret yang telah atau sedang dilakukan oleh FNKSDA. (D. Setiawan, Pewawancara) 
Sanapiah, F. (1995). Format-format Penelitian Sosial, Dasar-dasar dan Aplikasi. Jakarta: Rajawali Press.

Smith, C. (1996). Disruptive Religion: The Force of Faith in Social-Movement. London: Routledge.

Stevanus, K. (2019). Pelestarian alam sebagai perwujudan mandat pembangunan: suatu kajian etis-teologis. KURIOS (Jurnal Teologi dan Pendidikan Agama Kristen), 5(2), 94-108.

Ubaidillah, M. (2018). Wajah Baru Kiri Islam: Studi Gerakan Front Nahdliyin Untuk Kedaulatan Sumber Daya Alam (FNKSDA). Kontemplasi: Jurnal Ilmu-Ilmu Ushuluddin, 6(2), 251-270.

Widayati, A. (2019). Reaktualisasi Perjuangan Nahdlatul Ulama dalam Mewujudkan Kedaulatan Sumber Daya Agraria (Studi Gerakan Demokrasi Radikal pada FNKSDA). BHUMI: Jurnal Agraria dan Pertanahan, 5(1), 84-98.

Yafie, A. (2006). Merinstis Fikih Lingkungan. Jakarta: Ufuk Press.

Ziaulhaq, M. (2020). Pendekatan Sayyed Hossein Nasr dalam Kerangka Studi Agama-Agama. Modul Sosialisasi Toleransi Beragama, 88. 